$\sqrt{B}$

J. Bio-Sci. 26: 15-24, 2018

ISSN 1023-8654

http://www.banglajol.info/index.php/JBS/index

\title{
EFFECT OF SOME ENVIRONMENTAL CONDITIONS ON THE GROWTH OF RHIZOBIUM SPECIES
}

\author{
FO Ekundayo $0^{1,2^{*}}$, EA Ekundayo ${ }^{1,3}$, L Aladesuru ${ }^{1}$ and AA Salami ${ }^{1}$ \\ ${ }^{1}$ Department of Microbiology, Federal University of Technology, Akure, Nigeria \\ 2Department of Biological Sciences, Elizade University, Ilara-Mokin, Nigeria \\ ${ }^{3}$ Department of Biological Sciences, AfeBabalola University, Ado-Ekiti, Nigeria
}

\begin{abstract}
Rhizobium species are involved in symbiotic relationship which can be exploited in agriculture to enhance crop and pasture growth without the addition of nitrogen fertilizers. However, a number of environmental factors are known to affect the symbiotic efficiency of Rhizobium. This current study evaluated tolerance of Rhizobium species isolated from root nodules of cowpea obtained from Akure, Nigeria to variation in temperature, $\mathrm{pH}$ levels, salt concentrations, heavy metals as well as antibiotics. Three Rhizobium species were isolated from root nodules of Vignaunguiculata and Phaseolus vulgaris after 34 days of planting yeast extract mannitol agar (YEMA). Their tolerance to environmental factors such as temperature, $\mathrm{pH}$, sodium chloride, heavy metals as well as antibiotics was determined. All the isolates grew very well at $28^{\circ} \mathrm{C}$, moderately at $37^{\circ} \mathrm{C}$ but their growth was hampered at $50^{\circ} \mathrm{C}$. Maximal growth was observed at neutral pH. However, Sinorhizobium sp showed high tolerance to pH 7.0. Also, the isolates showed high tolerance to low concentration of sodium chloride $(0.1 \%)$ and heavy metals with reduction in their optical density at higher concentrations. Rhizobium sp showed high level of tolerance at 4\% compared to Mesorhizobium sp. and Sinorhizobium sp. Rhizobium spp. showed resistance to all the antibiotics investigated while Mesorhizobium sp. was sensitive to only to pefloxacin and sparfloxacin, while Sinorhizobium sp. was only sensitive to pefloxacin. The isolates in this study can be assessed for their suitability as inoculants forcowpea in soils below temperature $50^{\circ} \mathrm{C}$ and at neutral $\mathrm{pH}$.
\end{abstract}

Key words: Rhizobium species, Resistance, Heavy metals, Antibiotics, Salt

\section{Introduction}

Rhizobium species are among unique soil bacteria which have beneficial effects on the growth of plants (Willey et al. 2011). They either live in the rhizosphere or rhizoplane of the soil or also are majorly found within the root nodules of host legumes where they help convert atmospheric nitrogen to ammonia and provides organic nitrogenous compounds to the plants (Al-Mujahidy et al. 2013, Bhattacharya et al. 2013, Shoukry et al. 2013). The nitrogen-fixing symbiotic relationship has been exploited in agriculture to enhance crop and pasture growth without the addition of nitrogen fertilizers affirmed by Zahran et al. (2012).

Characterization of indigenous populations of rhizobia for their resistance to adverse or harsh environmental factors is important before their selection for nursery inoculation (Singh et al. 2008). Tolerance tests are usually performed in vitro exposing the strains to adverse conditions that mimic those that naturally occur in the soil (Miguel and Moreira 2001, Nóbrega et al. 2004, Medeiros et al. 2007, Xavier et al. 2007, Chagas Júnior et al. 2010). Slight variation in $\mathrm{pH}$ of the medium might have significant effects on the growth of the organism and extremes $\mathrm{pH}$ can be a major factor limiting microorganism in soil (Singh et al. 2008).

*Author for correspondence: feokunday02002@yahoo.com; foekundayo@futa.edu.ng 
Deora et al. (2010) reported that Rhizobium grew best at neutral pH 7.0 and no growth was observed in medium with $\mathrm{pH} 4.0$ and 9.0. However, some strains of fast-growing rhizobia such as Rhizobium loti, $R$. trifolii and $R$. tropici, have been found to be highly acid-tolerant.

Salinity is one of the major factors restricting the symbiotic nitrogen fixation and known to significantly reduce nodulation in legumes as opined by Shetta et al. (2011). Increasing salt concentration may have detrimental effects on rhizobia population while salt tolerant rhizobia may have the potential to improve yield of legumes under salinity stress. Survival and growth in saline environments are the result of adaptive processes, such as ions transport and osmotic solute synthesis and accumulation, which lead to osmotic adjustment and protein turnover for cellular repair (Mabrouk et al. 2012). High salt can directly impair rhizobia-legume early interactions during nodule formation and development. It is known that salt stress significantly alters the Rhizobium-legume symbiosis by reducing plant growth and photosynthesis, and hence nitrogen demand thus, decreasing survival and proliferation of rhizobia in the soil or by inhibiting early symbiotic events, such as chemotaxis and root hair colonization, thus directly interfering with root nodule function as explained by Irum et al. (2009). Singh et al. (2008) also reported that Rhizobium cells were able to grow in $1 \% \mathrm{NaCl}$ containing medium but were unable to grow in higher concentrations. Rhizobium strains from arid and saline areas are highly salt-tolerant and withstand high $\mathrm{NaCl}$ levels up to $5-10 \%$ as noted by Al-Shaharani et al. (2011) and Shetta et al. (2011).

Alexandre and Oliveira (2012) as well as Boboye et al. (2012) observed that Rhizobium strains grew best at 28 and $30^{\circ} \mathrm{C}$ after 3 to 7 days of the incubation. About $90 \%$ of cowpea Rhizobium strains, obtained from hot and dry environments of the Sahel Savannah grew well at $40^{\circ} \mathrm{C}$ while $R$. phaseoli strains persisted at $45^{\circ} \mathrm{C}$ (Zahran et al. 2012). The lowest $R$. meliloti populations were present in the soil with the highest concentration of heavy metal. However, rhizobia from Vieia faba cultivated in sewage sludge contaminated soils, were highly resistant to zinc and lead at concentrations of 650 and $350 \mathrm{ppm}$ respectively. Similarly, metal-resistant symbiont; Mesorhizobium metallidurans has been identified from the legume Anthyllis vulneraria growing on metallicolous soil in France as confirmed by Vidal et al. (2009).

Antibiotic tolerance is of particular importance in all soil conditions because it is one of the mechanisms rhizobia can use to overcome the antagonism exerted by other organisms in the soil, including several genera of Actinobacteria, among others (Moreira and Siqueira, 2006). This present investigation evaluated tolerance of Rhizobium species isolated from root nodules of cowpea obtained from Akure, Nigeria to variation in temperature, $\mathrm{pH}$ levels, salt concentrations, heavy metals as well as antibiotic.

\section{Materials and Methods}

Three Rhizobium species isolated from the root nodules of cowpea were collected from the Department of Microbiology, Federal University of Technology, Akure, Nigeria. The isolates were maintained on Yeast Mannitol Salt Agar (YEMA) at $4^{\circ} \mathrm{C}$ for temporary storage.

\section{Effect of variation in temperature on Rhizobium spp.}

In order to evaluate the tolerance of the isolates to different temperature levels, Rhizobium species were inoculated on YEMA medium and incubated at 25,37 and $50^{\circ} \mathrm{C}$ according to the method of Bhattacharya et al. (2013). 


\section{Effect of changes in pH levels on Rhizobium spp.}

Isolates were tested for their ability to grow at different $\mathrm{pH}$ levels of 4.0, 7.0 and 9.0. Ten $\mathrm{ml}$ of the broth was dispensed into the test tube, corked and sterilized at $121^{\circ} \mathrm{C}$ for 15 minutes, it was allowed to cool and $1 \mathrm{ml}$ of 24 hours old culture of Rhizobium was inoculated, incubated at $25^{\circ} \mathrm{C}$ for 48 hours. The absorbance was read on the spectrophotomer at $420 \mathrm{~nm}$ (Singh et al. 2008).

\section{Effect of different salt ( $\mathrm{NaCl}$ ) concentrations on Rhizobium spp.}

Yeast extract mannitol broth was supplemented with varying concentrations of $\mathrm{NaCl}(0.1,0.5,1,2,4 \%)$ to assess tolerance of Rhizobium to salt (Penna et al. 2011). A $1 \mathrm{ml}$ of 24 hours old culture was then inoculate on the sterile medium and incubated at $25^{\circ} \mathrm{C}$ after which the absorbance was read on the spectrophotometer (Corning Calorimeter 253) at $420 \mathrm{~nm}$ to determine the number of cell capable of surviving the osmotic pressure using Shoukry et al. (2013) method.

\section{Metal tolerance of Rhizobium spp.}

A $1 \mathrm{ml}$ of the 24 hours old culture was inoculated on sterile yeast extract mannitol broth (YEMB) amended with vary concentration of zinc, manganese, copper and iron $(0.02,0.25,0.50,1.0$ and $2.0 \%)$ to determine the tolerance of the isolates. The number of cell was determined on the spectrophotometer (Corning calorimeter 253) by measuring the absorbance using Zahran et al. (2012) method.

\section{Tolerance of Rhizobium to antibiotics}

Antibiotic tolerance of the isolates was analyzed aseptically using antibiotic disc containing different antibiotics on sterile Muller Hinton agar on which the isolates have been inoculated on different sets on petri dishes. The disc of the following antibiotics ( $\mu \mathrm{g} / \mathrm{disc})$ : septrin (30), chloramphenicol (30), sparfloxacin (10), ciprofloxacin (10), amoxacilin (30), augmentin (30), gentamyan (10), pefloxacin (30), tarvid (10), streptomycin (30) were used to test the ability of each isolate to resist the given antibiotic doze. The plates were incubated for at $28^{\circ} \mathrm{C}$ for 24 hours which the presence or absence of an inhibition zone was noted, indicating sensitivity or tolerance to the antibiotics The growth around the disc means that the isolate showed apparent resistance to the antibiotic doze using Shoukry et al. (2013) method.

\section{Results}

\section{Effect of temperature on Rhizobium spp.}

Change in temperature affected the growth of the Rhizobium spp. At $28^{\circ} \mathrm{C}$ there was visible growth of the organisms, at $37{ }^{\circ} \mathrm{C}$ there was slight growth of the organism and at $50^{\circ} \mathrm{C}$ incubation no growth was observed (Table 1).

\section{Tolerance of Rhizobium species to $\mathrm{pH}$ and salt ( $\mathrm{NaCl}$ )}

There was decrease in cell numbers at pH 4 and 9 . Sinorhizobium sp. showed high tolerance at pH 7 (Fig. 2). The isolated Rhizobium species showed tolerance to low concentration of sodium chloride at $0.1 \%$ but at high concentration of $4 \%$, there was decrease in number of cells as determined through the absorbance read from the spectrophotometer. Rhizobium sp. showed high level of tolerance at $4 \%$ compared to Mesorhizobium sp. and Sinorhizobium sp. as shown in Fig. 1. 


\section{Tolerance of Rhizobium species to some heavy metals}

All the isolates were sensitive to high concentration of zinc (2\%) but low concentration of $0.02 \%$ supported their growth. There was decrease in cell number with increase in concentration as shown in Fig. 3. Similar trends were observed for all the other metals (Fig. 4-6).

\section{Tolerance of Rhizobium species to antibiotics}

Rhizobium sp. showed resistance to all the antibiotics investigated but Mesorhizobium sp. was sensitive to only to pefloxacin and sparfloxacin, while Sinorhizobium sp. was only sensitive to pefloxacin (Table 2).

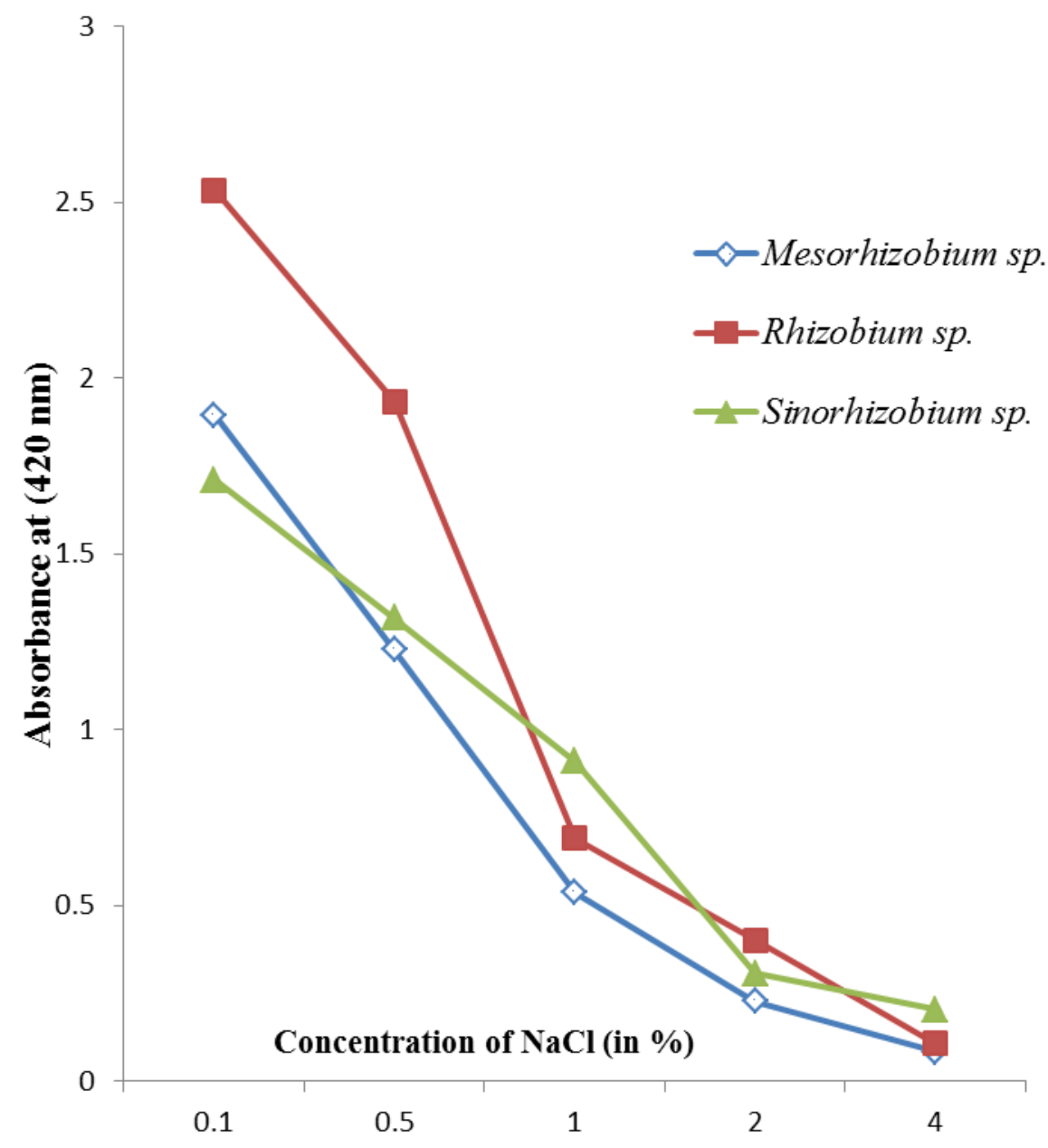

Fig. 1. Tolerance of Rhizobium species to different concentration of sodium chloride. 


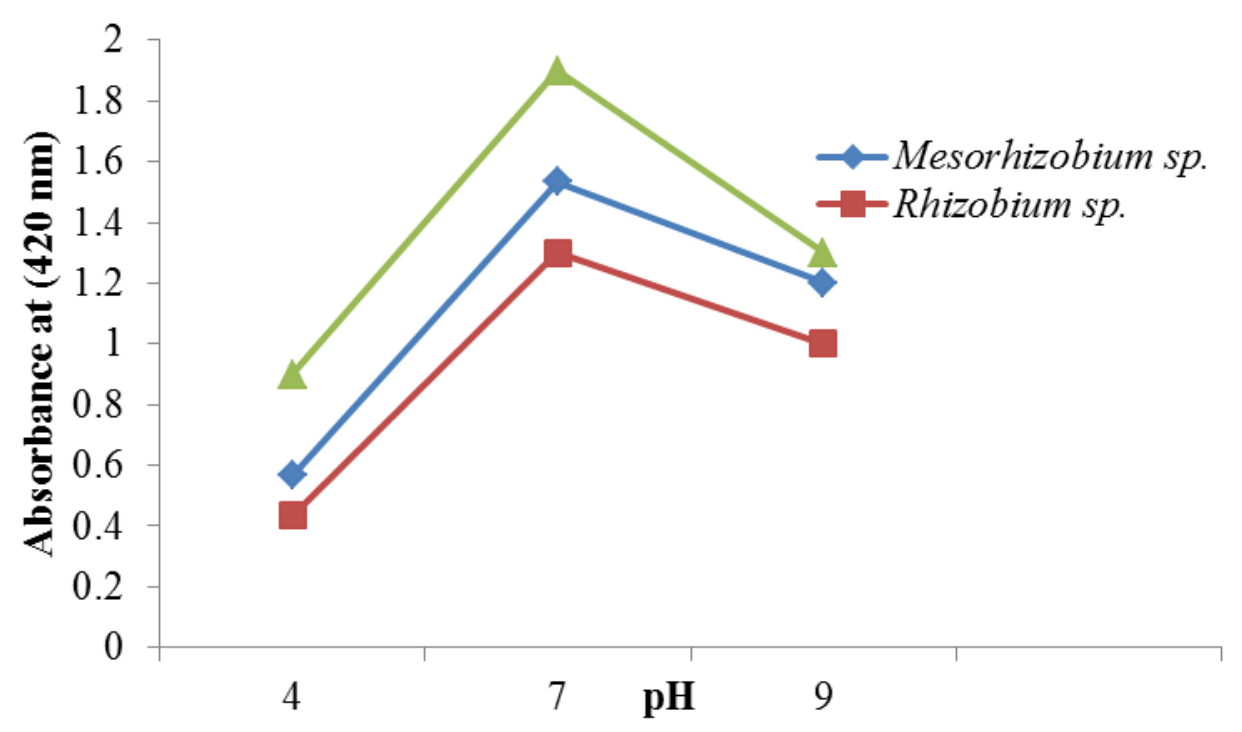

Fig. 2. pH Tolerance of Rhizobium species.

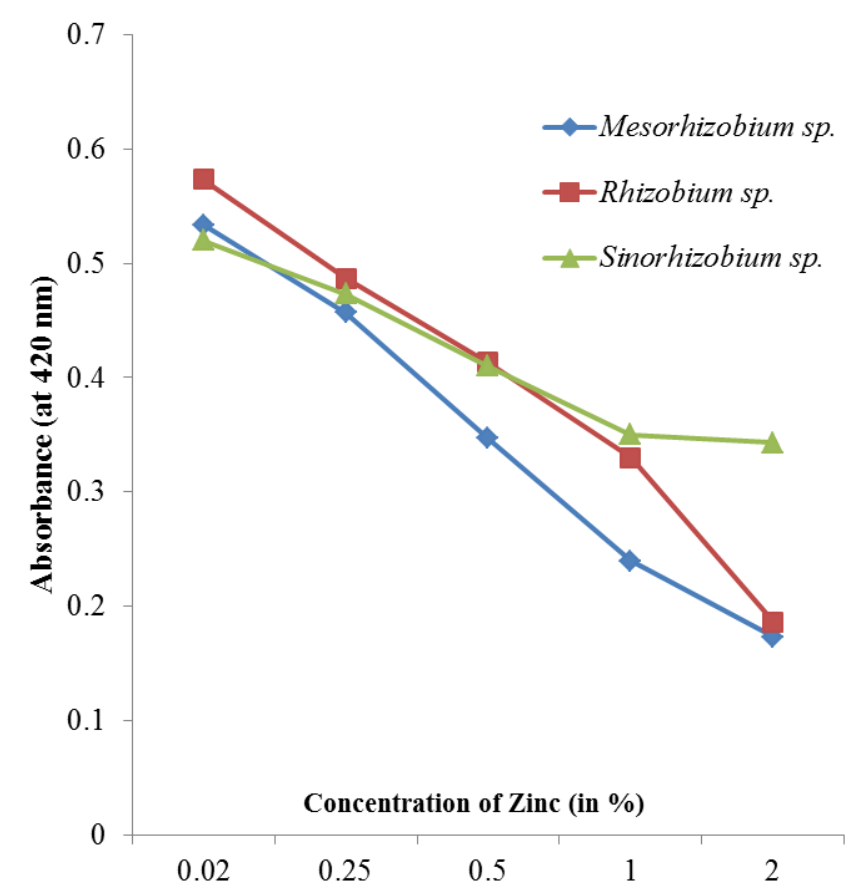

Fig. 3. Tolerance of Rhizobium species to zinc. 


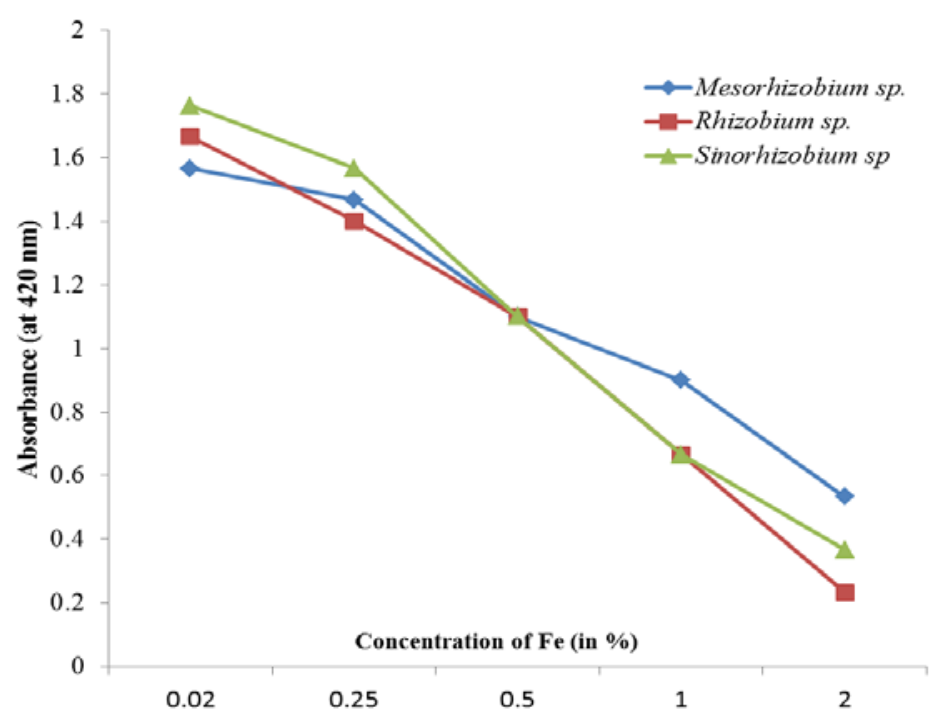

Fig. 4. Tolerance of Rhizobium species to iron.

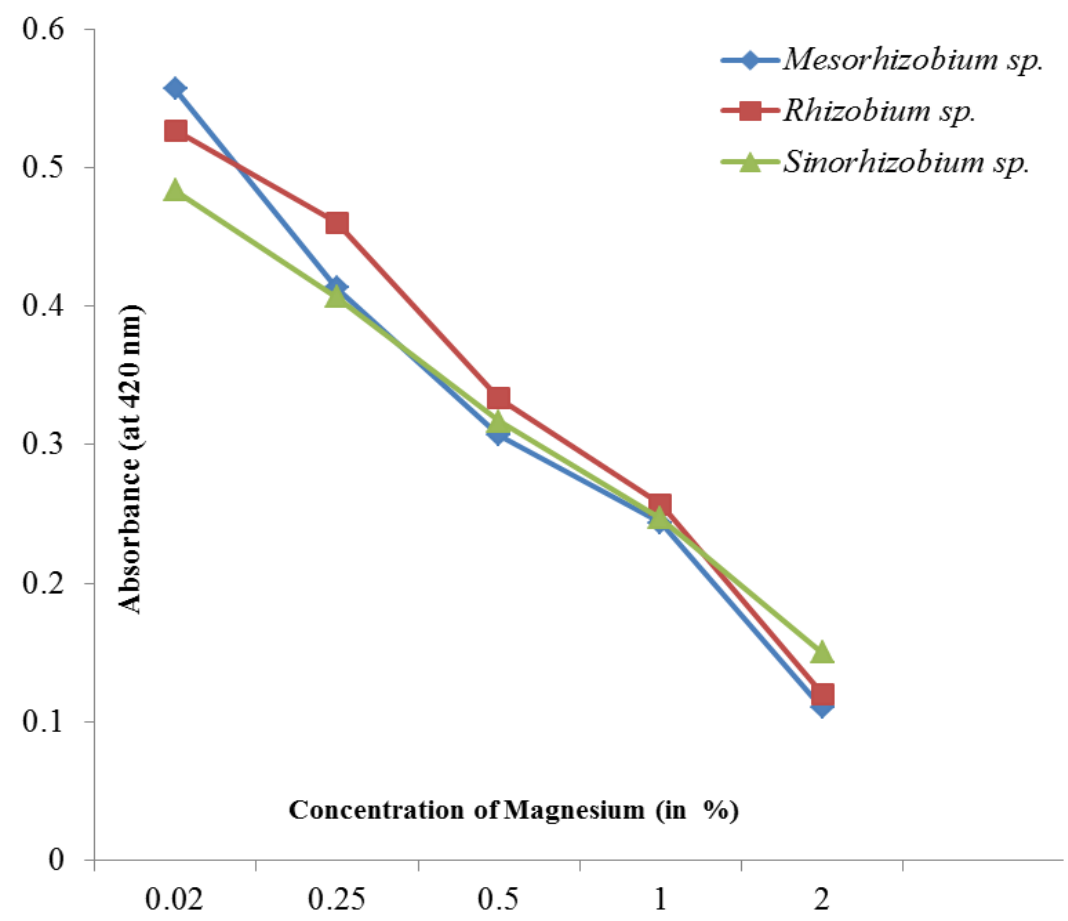

Fig. 5. Tolerance of Rhizobium species to magnesium. 


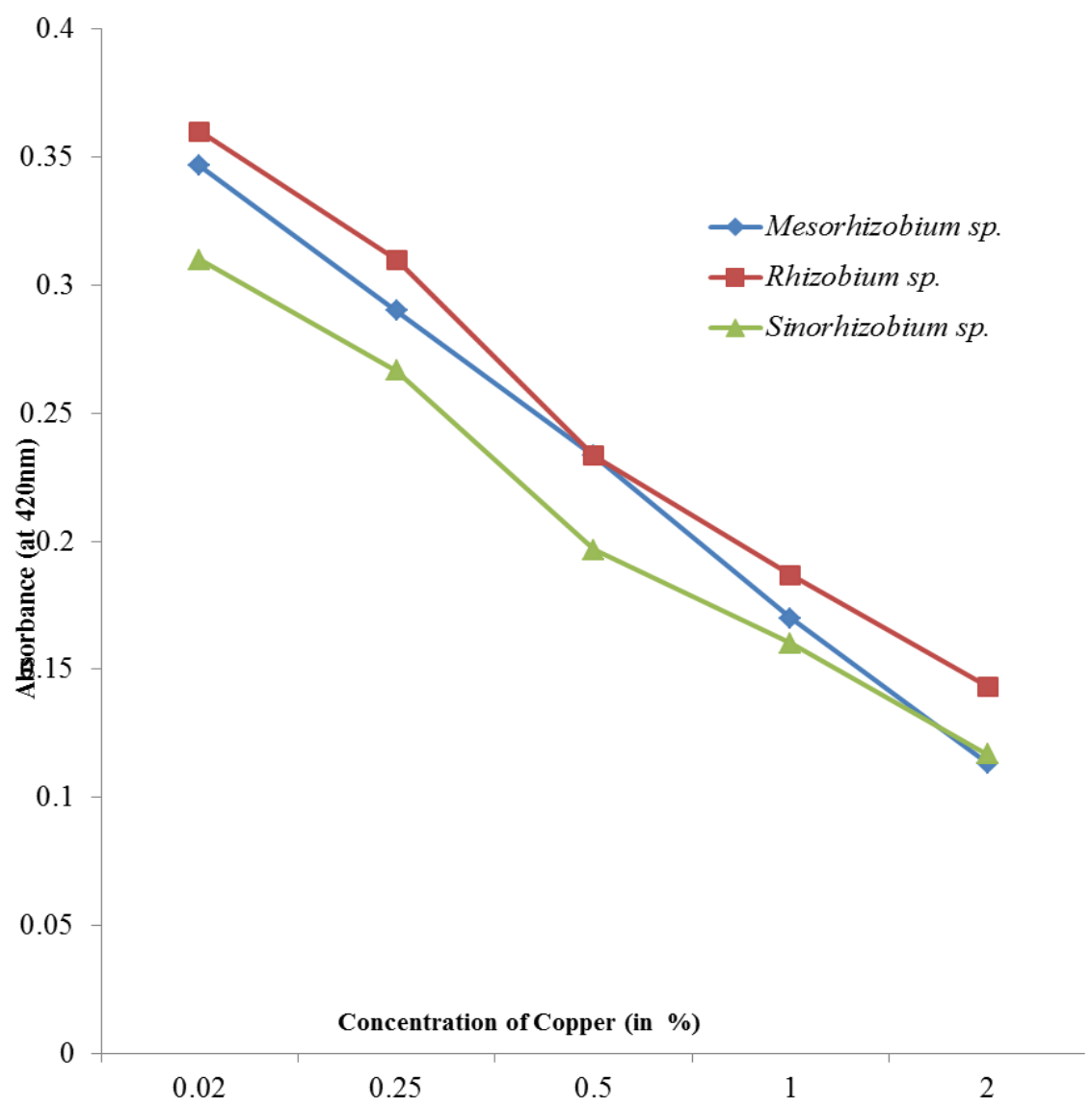

Fig. 6. Tolerance of Rhizobium species to copper. 
Table 2. Tolerance of Rhizobium species to antibiotics

\begin{tabular}{|c|c|c|c|c|c|c|c|c|c|c|}
\hline Microorganisms & PEF & SXT & $\mathrm{CH}$ & $\mathrm{SP}$ & CPX & $A M$ & $A U$ & $\mathrm{CN}$ & OFX & S \\
\hline A & 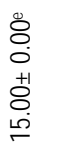 & $\begin{array}{l}\text { ठ̊ } \\
0 \\
+1 \\
\text { ○े } \\
\text { i }\end{array}$ & $\begin{array}{l}\stackrel{0}{N} \\
0 \\
0 \\
+1 \\
0 \\
0 \\
0 \\
0\end{array}$ & 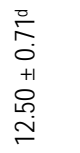 & $\begin{array}{l}\text { ठे } \\
0 \\
+1 \\
\text { +1 } \\
8 \\
0\end{array}$ & $\begin{array}{l}0 \\
8 \\
0 \\
+1 \\
8 \\
8 \\
0\end{array}$ & $\begin{array}{l}\pi \\
0 \\
0 \\
+1 \\
+1 \\
8 \\
0\end{array}$ & $\begin{array}{l}0 \\
8 \\
0 \\
+1 \\
+1 \\
8 \\
0\end{array}$ & $\begin{array}{l}\text { वू } \\
0 \\
0 \\
+1 \\
8 \\
0\end{array}$ & $\begin{array}{l}\tilde{0} \\
0 \\
0 \\
+1 \\
8 \\
0 \\
0\end{array}$ \\
\hline B & $\begin{array}{l}0 \\
8 \\
0 \\
+1 \\
8 \\
0 \\
0\end{array}$ & $\begin{array}{l}\text { oे } \\
0 \\
+1 \\
\text { ठे } \\
\dot{m}\end{array}$ & $\begin{array}{l}\text { ठ̊ } \\
0 \\
+1 \\
\stackrel{+1}{0} \\
0\end{array}$ & $\begin{array}{l}\text { o̊ } \\
0 \\
0 \\
+1 \\
8 \\
0\end{array}$ & $\begin{array}{l}\text { 8ू } \\
0 \\
+1 \\
8 \\
0 \\
0\end{array}$ & $\begin{array}{l}0 \\
8 \\
0 \\
+1 \\
8 \\
8 \\
0\end{array}$ & $\begin{array}{l}\text { o̊ } \\
0 \\
0 \\
+1 \\
8 \\
0\end{array}$ & $\begin{array}{l}0 \\
8 \\
0 \\
+1 \\
+1 \\
8 \\
0\end{array}$ & 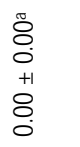 & $\begin{array}{l}0 \\
0 \\
0 \\
+1 \\
8 \\
0\end{array}$ \\
\hline C & $\begin{array}{l}\stackrel{\circ}{0} \\
\text {. } \\
+1 \\
\text { +1 } \\
\text { m. }\end{array}$ & $\begin{array}{l}\text { 8ू } \\
0.0 \\
+1 \\
\text { +1 } \\
0\end{array}$ & $\begin{array}{l}\text { o̊ } \\
0 \\
0 \\
+1 \\
8 \\
0\end{array}$ & $\begin{array}{l}0 \\
8 \\
0 \\
+1 \\
+1 \\
8 \\
0\end{array}$ & $\begin{array}{l}8 \\
0 \\
0 \\
+1 \\
8 \\
0 \\
0\end{array}$ & $\begin{array}{l}\text { סू } \\
0 \\
0 \\
+1 \\
8 \\
0\end{array}$ & 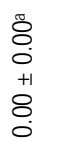 & $\begin{array}{l}0 \\
8 \\
0 \\
+1 \\
\text { +1 } \\
0\end{array}$ & $\begin{array}{l}0 \\
0 \\
0 \\
+1 \\
8 \\
0 \\
0\end{array}$ & $\begin{array}{l}\widetilde{0} \\
0 \\
0 \\
+1 \\
8 \\
0\end{array}$ \\
\hline
\end{tabular}

$\mathrm{PEF}=$ Pefloxacin, $\mathrm{SXT}=$ Septrin, $\mathrm{CH}=$ Chloraphenicol, $\mathrm{SP}=$ Sparfloxacin, $\mathrm{CPX}=$ Ciprofloxacin, $\mathrm{AM}=$ Amoxacillin, $\mathrm{AU}=$ Augmentin, $\mathrm{CN}=$ Gentamycin, $\mathrm{OFX}=$ Tarvid, $\mathrm{S}=$ Streptomycin, $\mathrm{A}=$ Mesorhizobium sp., $\mathrm{B}=$ Rhizobiumsp., $\mathrm{C}=$ Sinorhizobium sp.

\section{Discussion}

Growth of the isolates was recorded at $28^{\circ} \mathrm{C}$ which was in line with Boboye et al. (2012) and slight growth at $37^{\circ} \mathrm{C}$ but no growth were recorded at $50^{\circ} \mathrm{C}$ in contrary to Singh et al. (2008) but agree with Bhattacharya et al. (2013). It has been previously reported that temperatures above $40^{\circ} \mathrm{C}$ inhibit rhizobia growth (Osa-Afiana and Alexander 1982, Maâtallah et al. 2002). There was decrease in cell number at pH 4 while the highest cell number was obtained at pH 7.0 This is contrary to Zahran et al. (2012) who were able to isolate some Rhizobiumspecies such as $R$. loti, $R$. trifolii and $R$. tropici which were highly acid-tolerant. Florentino et al. (2010) also observed that Bradyrhizobium species were tolerant to pH levels 4 to 9. Tolerance to different pH levels is a desirable characteristic for potentially commercial inoculants strains.

The organisms were unable to grow very well at $4 \%$ compared to $0.1 \%$ of $\mathrm{NaCl}$ which had the highest number of cell. The rhizobia nodulating Leucaena that grew in slightly salt-soils in Egypt were tolerant to about $4 \% \mathrm{NaCl}$. It has been observed by previous studies that rhizobial strains that produced more EPS were more tolerant to salinity (Eaglesham et al. 1987, Xavier et al. 1998, Freitas et al. 2007, Xavier et al. 2007). Also, alterations in cell membrane composition and trehalose production have been reported to be adaptation processes allowing rhizobia survival under saline stress conditions (Streeter 2003, Medeot et al. 2007). All isolates grew at $0.01 \%$ of zinc, copper, manganese and iron but were unable to tolerate these metals at high concentration of $4 \%$ indicated by drastic decrease in their cell number and this in agreement with the previous study of Zahran et al. (2012) but in contrary to Vidal et al. (2009). Cevheri et al. (2011) also observed that some of the Rhizobium species they studied showed resistance to $\mathrm{Zn}$ and $\mathrm{Cu}$ at high concentrations. A plasmid of approximately $70 \mathrm{~kb}$ was reported to be responsible for resistance to metal in Rhizobium isolates by Lakzian et al. (2002). 
Furthermore, all the Rhizobium species were resistant to tarvid, gentamycin, ciprofloxacin, augmentin, amoxicillin and streptomycin which agree with Shetta et al. (2011) but disagree with Bhattacharya et al. (2013). The wide range of antibiotic tolerance partially explains the success under field conditions of the inoculant strains currently recommended (Lacerda et al. 2004, Soares et al. 2006), as this tolerance is a possible mechanism to overcome antagonism exerted by other organisms in the soil.

\section{Conclusion}

The isolates in this study can be assessed for their symbiotic efficiency and suitability as inoculant for cowpea in soils below temperature $50^{\circ} \mathrm{C}$ and at neutral pH. Also, the resistance of the isolates to some of the antibiotics tested might make them better competitor than others in the presence of antagonistic soil microbes.

\section{References}

Alexandre A and Oliveira S (2012). Response to temperature stress in rhizobia. Critical Review of Microbiology, 10: 3109.

Al-Mujahidy J, Hassan M, Rahman M and Mamun ANM (2013). Isolation and characterization of rhizobium spp. and determination of their potency for growthfactor production. International Research Journal of Biotechnology, 4(7): 117-123.

Al-Shaharani TS and Shetta ND (2011). Evaluation of growth, nodulation and nitrogen fixation of two Acacia species under salt stress. World Applied Science Journal, 13: 256-265.

Bhattacharya C, Deshpande B and Pandey B (2013). Isolation and characterization of Rhizobium sp. from root of legume plant (Pisum sativum) and its antibacterial activity against different bacterial strains. International Journal of Agricultural Food Science, 3(4): 138-141.

Boboye B, Ogundeji B and Evbohoin $\mathrm{H}$ (2012). Mutational research for high temperature $\left(60^{\circ} \mathrm{C}\right)$ tolerant variant of Rhizobium species. Journal of Advances in Biology and Biotechnology, 2: 255-262.

Cevheri C, Küçük C and Çetin E (2011). Fungicide, antibiotic, heavy metal resistance and salt tolerance of root nodule isolates from Vicia palaestina. African Journal of Biotechnology, 10(13): 2423-2429.

Chagas Júnior AF, Oliveira LA and Oliveira AN (2010). Caracterizaçãofenotípica de rizóbionativosisolados de solos da Amazônia e eficiênciasimbióticaemfeijãocaupi. Acta Scientiarum, 32: 161-169.

Deora GS and Singal K (2010). Isolation, biochemical characterization and preparation of bio fertilizers using Rhizobium strain for commercial use. Biotechnological Research, 3(2): 132-136.

Eaglesham ARJ, Stowers MD, Maina ML, Goldman BJ, Sinclair MJ and Ayanaba A (1987). Physiological and biochemical aspects of diversity of Bradyrhizobium sp. (Vigna) from three West African soils. Soil Biology and Biochemistry, 19: 575-581.

Florentino LA, de Sousa PM, Silva J S Karina Barroso Silva KB and Moreira FM (2010). Diversity and efficiency of Bradyrhizobium strains isolated from soil samples collected from around Sesbaniavirgata roots using cowpea as trap species. Revista Brasileira de Ciênciado Solo, 34: 1113-1123.

Freitas ADS, Vieira CL, Santos CERS, Stamford NP and Lyra MCCP (2007). Characterization of isolated rhizobia of Pachyrhyzuzerosus cultivated in saline soil of the State of Pernambuco, Brazil. BragantiaCampinas, 66 (3): $497-$ 504.

Irum N, Asghari B and Tamoor U (2009). Morphological, biochemical and molecular characterization of Rhizobia from Halophytes of Khewra salt range and Attock. Journal of Botany, 41(6): 3159-3168.

Lacerda AM, Moreira FMS, Andrade MJB and Soares ALL (2004). Yield and nodulation of cowpea inoculated with selected strains. Revista Ceres, 51: 67- 82. 
Lakzian A, Murphy P, Turner A, Beynon VL and Giller KE (2002). Rhizobium leguminosarum. Vicia populations in soils with increasing heavy metal contamination: abundance, plasmid profiles, diversity and metal tolerance. Soil Biology and Biochemistry, 34: 519-529.

Mabrouk Y and Belhadj O (2012). Enhancing the biological nitrogen fixation of leguminous crops grown under stressed environments. African Journal of Biotechnology, 11: 10809-10815.

Maâtallah J, Berraho EB, Muñoz S, Sanjuan J and Lluch C (2002). Phenotypic and molecular characterization of chickpea rhizobia isolated from different areas of Morocco. Journal of Applied Microbiology, 93: 531- 540.

Medeiros ED, Silva KJP, Martins CM and Borges WL (2007). Tolerance of nitrogen fixing bacteria Rio Grande do Norte at temperature and salinity. Revista De Biologia E Ciências Da Terra, 7: 160-168.

Medeot DB, Bueno MA, Ardanelli MS and Lema MG (2007). Adaptational changes in lipids of Bradyrhizobium SEMIA 6144 nodulating peanut as a response to growth temperature and salinity. Current Microbiology, 54:31-35.

Miguel DL and Moreira FMS (2001). Influence of pH of culture medium and peat on the behavior of Bradyrhizobium strains. Brazilian Journal of Soil Science, 25: 873-883.

Moreira FMS and Siqueira JO (2006). Microbiology and soil Biochemistry. Lavras, Univ. de Federal de Lavras. pp. 729.

Nóbrega RSA, Moreira FMS, Siqueira JO and Lima AS (2004). Phenotypic characterization and diversity of associative diazotrophic bacteria isolated from soils in rehabilitation after bauxite mining. Brazilian J. Soil Sci., 28: 269-279.

Osa-Afiana LO and Alexander M (1982). Differences among cowpea rhizobia in tolerance to high temperature and desiccation in soil. Applied and Environmental Microbiology, 43: 435-439.

Penna C, Massa R, Olivieri F, Gutkind G and Cassan F (2011). A simple method to evaluate the number of Bradyrhizobia on soybean seeds and its implication on inoculant quality control. Springer Open Journal, 1: 21.

Shetta ND, Al-Shaharan TS and Abdel-Aal BT (2011). Identification and characterization of Rhizobium associated with woody legume trees grown under Saudi Arabia condition. American-Eurasian Journal of Agricultural and Environmental Sciences, 10(3): 410-418.

Shoukry AA, Khattab AA, bou-Ellai M and El-shabrawy H (2013). Molecular and biochemical characterization of new Rhizobium leguminosarum bioviciae strains isolated from different located of Egypt. Journal of Applied Science and Research, 9(11): 5864-5877.

Singh B, Kaur R and Singh K (2008). Characterization of Rhizobium strain isolated from the roots of Trigonella foenumgraecum (Fenugreek). African Journal of Biotechnology 7(20): 3671-3676.

Soares ALL, Pereira JPAR, Ferreira PAA, Vale HMM, Lima AS, Andrade MJB and Moreira FMS. (2006). Agronomic efficiency of selected rhizobia strains and diversity of native nodulating populations in Perdões (MG - Brazil). Icowpea. Brazilian Journal of Soil Science, 30: 795-802.

Streeter JG (2003). Effect of trehalose on survival of Bradyrhizobium japonicum during desiccation. Journal of Applied Microbiology, 95: 484-491.

Vidal Cl, Chantreuil CM, Berge O, MaureL, Escarre J, Béna G, Brunel B and Cleyet-Marel JC (2009). Mesorhizobium metalliduran ssp. Nov., a metal-resistant symbiont of Anthyllis vulneraria growing on metallicolous soil in Languedoc, France. International Journal of Systemic and Evolutionary Microbiology, 59: 850-855.

Willey JM, Sherwood LM and Woolverton CJ (2011). Prescott's Microbiology ( $8^{\text {th }}$ edition). McGraw Hill, pp. 703-706.

Xavier GR, Martins LMV, Neves MCP and Rumjanek NG (1998). Edaphic factors as determinants for the distribution of intrinsic antibiotic resistance in a cowpea, rhizobia population. Biology and Fertility of Soils, 27: 386-392.

Xavier GR, Martins LM, Rumjanek NG and Neves MCP (2007). Tolerance of rhizobia of bean cowpea to salinity and temperature in in vitro condition. Caatinga Magazine, 20: 1-9.

Zahran HH, Abdel-Fattah M, Yasser MM and Mahmoud AM (2012). Diversity and environmental stress responses of rhizobial bacteria from Egyptian grain legumes. Australian Journal of Basic and Applied Sciences, 6(10): 571-583. 